www.asianjournalofmycology.org Article

Doi 10.5943/ajom/2/1/11

\title{
Leucodermia guzmaniana sp. nov. (Physciaceae, Lecanorales), a new species from Mexican cloud forest, and a key to Leucodermia in Mexico
}

\author{
Guzmán-Guillermo J*1, Díaz-Escandón $\mathbf{D}^{2}$ and Medel-Ortiz $\mathbf{R}^{3}$ \\ ${ }^{1}$ Facultad de Biología. Universidad Veracruzana, Veracruz, Mexico \\ ${ }^{2}$ Herbario de la Universidad Del Valle CUVC, Valle del Cauca, Colombia \\ ${ }^{3}$ Instituto de Investigaciones Forestales. Universidad Veracruzana, Veracruz, Mexico
}

Guzmán-Guillermo J, Díaz-Escandón D, Medel-Ortiz R 2019 - Leucodermia guzmaniana sp. nov. (Physciaceae, Lecanorales) a new species from Mexican cloud forest, and a taxonomical key of Leucodermia in Mexico. Asian Journal of Mycology 2(1), 209-212, Doi 10.5943/ajom/2/1/11

\begin{abstract}
Leucodermia guzmaniana Guzmán-Guillermo, Díaz-Escandón \& Medel is described as a new species of lichen fungus, being characterized by terminal soredia and marginal white cilia covered with a red pigment that reacts $\mathrm{K}+$ purple. The new species named after renowned Mexican Mycologist Dr. Gastón Guzmán. Leucodermia guzmaniana was collected in a cloud forest in Veracruz, Mexico.
\end{abstract}

Key words - Cloud forest - Heterodermia - new species

\section{Introduction}

Mexico has vast and unexplored lands, and there are still gaps in the information related to the diversity of various types of vegetation including neotropical ecosystems such as the cloud forest (CF) (Herrera-Campos et al. 2014). The cloud forest in Mexico is distributed mainly in central and southern regions of the country, and its fragmented distribution make it one of the most degraded ecosystem, with less than 50\% its original coverage (González-Espinosa et al. 2012, CONABIO 2010). The cloud forest is recognized by its high biodiversity in all groups of plants, trees, shrubs, epiphytes, herbs and its high levels of endemism (Williams-Linera 2015).

Leucodermia Kalb is a very common genus in Mexican cloud forest. It was recently established as a separate genus from Heterodermia Trevis. (Mongkolsuk et al. 2015), based on its ribbon-like, usually ascending, dichotomously branched lobes forming a three-dimensional thallus, with a thick revolute margin, absence of a lower cortex, and presence of sporoblastidia in the ascospores. Leucodermia is widespread around the world, from the tropics to temperate zones, commonly found at mid elevations in humid and usually well-conserved areas (Lücking et al. 2008). In the past few years, some Leucodermia species have been described based on newly recognized structures within the genus, such as cilia covered with dust-like pigments that react with $\mathrm{KOH}$ test in $H$. rubrotricha (Weerakoon \& Aptroot 2013) and phyllidia along the lobe margin in $L$. borphyllidiata (Mongkolsuk et al. 2015).

Currently, Leucodermia includes ten species listed in Mycobank and Index Fungorum. Nine of these have been recorded in Mexico and three species now classified within this genus have been described from this country (Kurokawa 1962). However, the total species richness in Leucodermia 
is not known; recent molecular works shows that the diversity in this genus may have been subestimated, and species delimitation in Heterodermia s.l. is still not well understood (DíazEscandón \& Lücking 2016). For instance, species like L. leucomelos likely represent a species complex.

\section{Materials and Methods}

The material was collected in cloud forest and secondary vegetation in Xalapa, Veracruz, Mexico. The description of the material is based on the characteristics considered by Mongkolsuk et al. (2015). Standard methods in lichenology were used according Brodo et al. (2001), including a $\mathrm{K}$ test for the cilia by cutting the cilia along the base and submerging them in a drop of $\mathrm{K}(\mathrm{KOH}$ $10 \%)$ solution and placing them over a slide. To analyze the secondary metabolites in the thallus and cilia, a TLC was performed, using solvent C (toluene/acetic acid 170:30), and the spots were analyzed with the program WINTABOLITES (Mietzsch et al. 1994). The material were deposited in XAL and XALU herbaria.

Leucodermia guzmaniana Guzmán-Guillermo, Díaz-Escandón \& Medel sp. nov.

Figs 1-3

Mycobank number: MB831662

Etymology - Dedicated to the later Dr. Gastón Guzmán, an eminent mycologist of Mexico who dedicated his life to mycology including the study of lichens (Guzmán-Dávalos \& Cifuentes 2018).

Typus - MEXICO, Veracruz, City of Xalapa, Ecological Park “El Haya”, May 10, 2015. J. Guzman-Guillermo, 71 (XAL-holotypus).

Additional specimens examined - MEXICO: Veracruz: municipality of Xalapa, city of Xalapa, Ecological Park “El Haya”. Mayo 10, 2015, J. Guzman-Guillermo, 92 (XALU); USBI Xalapa campus area, April 3, 2016, J. Guzman-Guillermo, 170,171, 172 (XAL); munipality of Coatepec, camino antiguo a Briones, January 8, 2017, J. Guzman-Guillermo, 501, 502, 503 (XAL).

Thallus foliose to sub-fruticose, loosely attached to ascendant, forming irregular, tangled mats, to 4-8 cm in diameter. Lobes 1-4 mm wide, ribbon-like, dichotomously branching, with flat to slightly circinate apices; lobes with long, simple, white to reddish, marginal cilia. Upper surface ivory to grayish green, epruinose, cortex 55-60 $\mu \mathrm{m}$ thick. Medulla white (see fig. C). Lower surface without cortex, slightly canaliculate, margins corticate, medulla compact to powdery and becoming sorediate, white throughout to light brownish. Soralia apical to subapical, soredia granulose, white to grey. Apothecia not seen. Pycnidia not seen. Photobiont a species of Trebouxia sp., forming clusters in the algal layer.

Chemistry - Cortex K+ yellow, C-, KC-, UV-; medulla K+ yellow turning orange to reddish, $\mathrm{C}$-; cilia $\mathrm{K}+$ violet (see Fig. $\mathrm{B}$ ); containing atranorin (major) and salazinic acid, and a unidentified pinkish compound with RF 60 (cilia).

Habitat and distribution - Only known from few localities in Xalapa, Veracruz, Mexico. Mainly growing on tree trunks on cloud forest or secondary vegetation in parks, Pinus sp., Liquidambar styrasiflua, Quercus sp., Spathodea campanulata, small shrubs such as Gardenia sp. and Rhododendron sp., and occasionally growing over mosses.

\section{Discussion}

Leucodermia guzmaniana is characterized by its red marginal cilia. It is most similar to $L$. leucomelos (L) Kalb, which has white to mostly black marginal cilia that lack any pigment. The new species differs from L. leucomelos by its white to reddish marginal cilia with a distinct $\mathrm{K}+$ violet reaction, which is not caused by the decay of salacinic acid as it may happen in other Heterodermia s.l. species with reddish tips and sometimes pinkish cilia (Kurokawa 1962, Trass 2000, Moberg 2011). Heterodermia rubrotricha Weerakoon \& Aptroot has the same $\mathrm{K}+$ violet reaction in the marginal cilia but it can be separated from $L$. guzmaniana by the black cilia, apothecia and narrower lobes (Weerakoon \& Aptroot 2013). Other similar species are $H$. kurokawae Trass and L. appalachensis (Kurok.) Kalb which has white cilia without pigment, but a 
yellow pigment on the lower surface. Yet another species with elongated lobes and similar appearance is $H$. arvidssonii Moberg, but it has pinkish pigment on the underside and darkening marginal cilia (Moberg 2011). The new species may also be confused with $H$. lineare Moberg \& T.H. Nash by its white marginal cilia, but $H$. lineare has a robust thallus and abundant apothecia (Table 1).
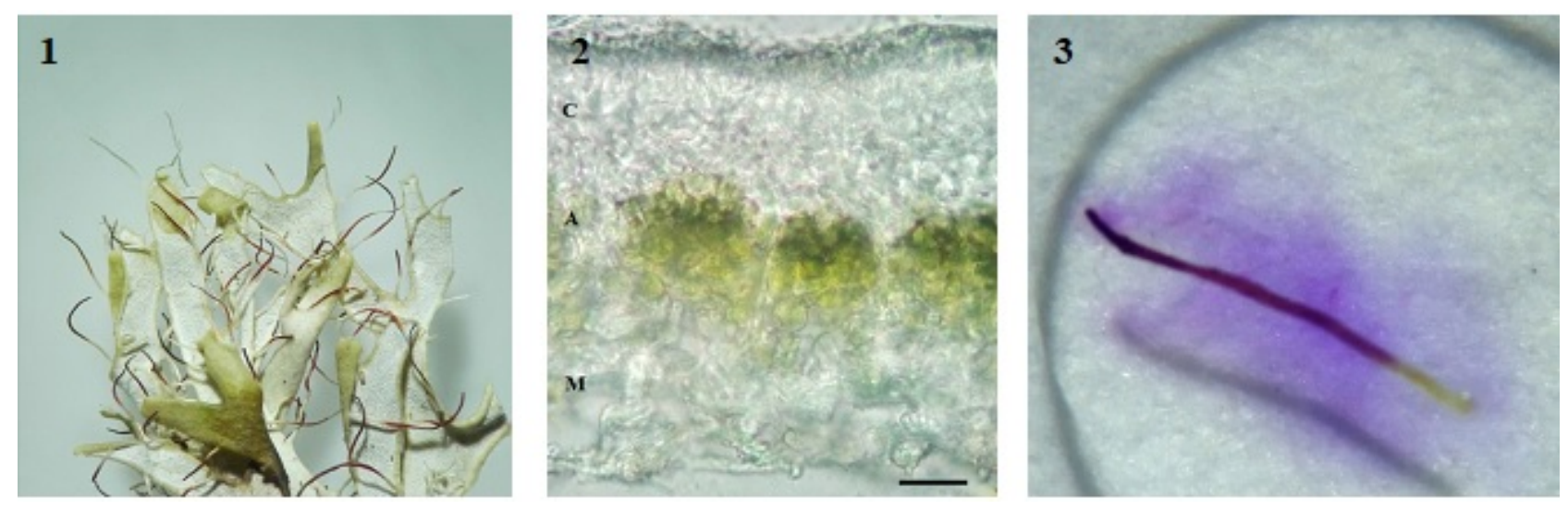

Fig. 1-3 - 1 Leucodermia guzmaniana Guzmán-Guillermo, Díaz-Escandón \& Medel typus. 2 Transversal section of a lobe, C: cortex, A: algal layer, M: medulla. 3 Red cilia showing a distinct $\mathrm{K}+$ violet reaction, in $\mathrm{KOH} 3 \%$. Scale Bars $=20 \mu \mathrm{m}$.

Table 1 Species similar to L. guzmaniana.

\begin{tabular}{lllll}
\hline Species & Cilia & Kin cilia & Lower surface & R. S. \\
\hline H. arvidssonii & White & Non-reactive & Pinkish & Soredia \\
H. kurokawae & White & Non-reactive & Yellowish patched & Apothecia \\
L. appalachensis & White & Non-reactive & Yellowish patched & Soredia \\
H. linearis & White & Non-reactive & White & Apothecia \\
L. guzmaniana & White & Purple & White & Soredia \\
H. rubrotricha & Black & Purple & White & Apothecia \\
L. leucomelos & Black & Non-reactive & White & Soredia \\
& & & & (apothecia \\
& & & & rare)
\end{tabular}

Notation: L.S: lower cortex, R.S: Reproduction structure. Moberg (2001), Weerakoon \& Aptroot (2013), Trass (2000).

\section{Key to known Leucodermia species in Mexico}

This key contains all known species of Leucodermia in Mexico. It is based on observations and collections examined by us. The CNALH database and others works were examined of Leucodermia species in Mexico.

1a. Cilia white, covered with a $\mathrm{K}+$ purple, red pigment L. guzmaniana

1b. Cilia white to black, without pigments .....................................................

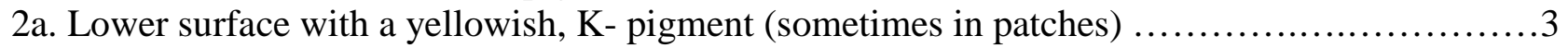

2b. Lower surface pure white or with red, $\mathrm{K}+$ purple arachnoid patches $\ldots \ldots \ldots \ldots \ldots \ldots \ldots \ldots \ldots \ldots . . . .4$ 3a. Pigment in patches on the lower surface, without apothecia ......L. appalachensis (Kurok.) Kalb 3b. Pigment all across the lower surface, sometimes with apothecia ........ lutescens (Kurok.) Kalb 4a. Lower surface with violet to red, $\mathrm{K}+$ purple arachnoid patches ...................... vulgaris s.l. 4b. Lower surface without pigmented patches, K- ............................................. 5

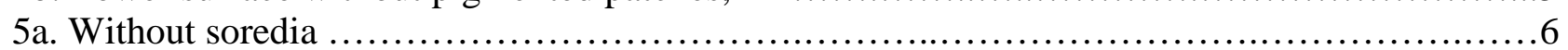


5b. Soredia present

6a. Medulla K-

L. ciliatomarginata (Linder) Kalb

6b. Medulla K+ yellow turning red, salazinic acid

.L. arsenei (Kurok.) Kalb

7a. Tips strongly circinate, lobes thin, common in highlands .............. L. circinalis (Zahlbr.) Kalb

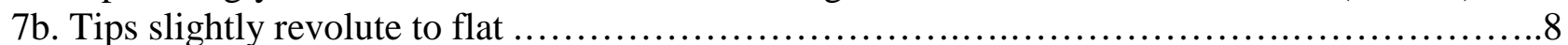

8a. Medulla K+ yellow turning red, salazinic acid ........................ leucomelos (L.) Kalb

8b. Medulla K+ yellow, without salazinic acid L. boryi (Fée) Kalb

\section{Acknowledgements}

The first author thanks to Dirección General de Investigaciones-Universidad Veracruzana for the fellowship of research assistant of Dr. Medel Ortiz. Thanks are also due to Juan Lara Carmona from the mycological collection (XAL herbarium) and to José Ortega from the XALU herbarium, Universidad Veracruzana, for all the help received during the development of this research. We are especially grateful to Dr. Robert Lücking for his recommendations and suggestions.

\section{References}

Brodo IM, Duran Sharnoff S, Sharnoff S. 2001 - Lichens of North America. Yale University, New Haven, EE.UU.

CONABIO. 2010 - El Bosque Mesófilo de Montaña en México: Amenazas y Oportunidades para su Conservación y Manejo Sostenible. Comisión Nacional para el Conocimiento y Uso de la Biodiversidad. 197 pp. Mexico D.F., Mexico.

Díaz-Escandón D, Lücking R. 2016 - Heterodermia Trevis. in Colombia: New Insights into generic divisions within Heterodermia sensu lato. In: Lumbsch, T, The 8th IAL Symposium - Lichens in Deep Time. Helsinki, Finland.

Herrera-Campos MA, Lüking R, Perez-Perez RE, Miranda-Gonzales R et al. 2014 - Diversidad de líquenes de México. Revista Mexicana de Biodiversidad 85, 82-99.

González-Espinosa M, Meave JA, Ramírez-Marcial N, Toledo-Aceves T et al. 2012 - Los bosques de niebla de México: conservación y restauración de su componente arbóreo. Ecosistemas 21(1-2), 36-52.

Guzmán-Dávalos L., Cifuentes J. 2018 - Gastón Guzmán, 26 August 1932-12 January 2016. Mycologia, 110(4), 791-794.

Kurokawa S. 1962 - A monograph of the genus Anaptychia. Nova Hedwigia 6, 1-108.

Lücking R, del Prado R, Lumbsch HT, Will-Wolf S et al. 2008 - Phylogenetic patterns of morphological and chemical characters and reproductive mode in the Heterodermia obscurata group in Costa Rica (Ascomycota, Physciaceae). Systematics and Biodiversity 6, 31-41.

Mietzsch E, Lumbsch HT, Elix JE. 1994 - WINTABOLITES (Mactabolites for Windows). Users manual and computer program, 2nd ed. Universität Essen.

Moberg R. 2011 - The lichen genus Heterodermia (Physciaceae) in South America, a contribution including five new species. Nordic Journal of Botany 29, 129-147.

Mongkolsuk P, Meesim S, Poengsungnoen V, Buaruang K et al. 2015 - The lichen family Physciaceae in Thailand-II. Contributions to the genus Heterodermia sensu lato. Phytotaxa 235(1), 1-66.

Trass H. 2000 - The lichen genus Heterodermia (Lecanorales, Physciaceae). Folia Cryptogamica Estonica 37, 93-108.

Weerakoon G, Aptroot A. 2013 - Some new lichen species from Sri Lanka, with a key to the genus Heterodermia in Sri Lanka. Cryptogamie, Mycologie 34, 321-328.

Williams-Linera G. 2015 - El bosque mesófilo de montaña, veinte años de investigación ecológica ¿qué hemos hecho y hacia dónde vamos? Madera y Bosques 21, 51-61. 